Vol. 11 (2002): 311-328.

\title{
Cropping system impact on soil quality determinants
}

\author{
Mauritz Vestberg, Sanna Kukkonen, Kaisa Saari, Marjatta Uosukainen \\ MTT Agrifood Research Finland, Plant Production Research, Laukaa Research and Elite Plant Station, \\ Antinniementie 1, FIN-41330 Vihtavuori, Finland, e-mail: mauritz.vestberg@mtt.fi
}

Ansa Palojärvi

MTT Agrifood Research Finland, Environmental Research, Soils and Environment, FIN-31600 Jokioinen, Finland

Tuomo Tuovinen

MTT Agrifood Research Finland, Plant Production Research, Plant Protection, FIN-31600 Jokioinen, Finland

Milja Vepsäläinen and Maarit Niemi

Finnish Environment Institute, PO Box 140, FIN-00251 Helsinki, Finland

\begin{abstract}
Worldwide interest in soil quality evaluation has increased rapidly throughout the past decade, prompting us to evaluate the long-term impact of four cropping systems on several biological, chemical and physical determinants of soil quality. We hypothesized that after 17 years several of the determinants would show significant differences between conventional cereal and low input/organic rotations. Four crop rotations were imposed on a silt soil from 1982 through 1999. Rotation A was a conventionally managed cereal rotation that received $100 \%$ of the recommended mineral fertilizer each year. Rotation B was also managed conventionally from 1982 until 1993, although it received only $50 \%$ of the recommended mineral fertilizer. From 1994 through 1999, rotation B was managed as an organic rotation. Rotations $\mathrm{C}$ and $\mathrm{D}$ were low-input rotations with plant residues returned either untreated (C) or composted (D) from 1982 until 1994. From 1994 through 1999, they were also managed organically. Significant decreases in extractable phosphorus $(\mathrm{P})$ and potassium were observed in rotations $\mathrm{C}$ and $\mathrm{D}$ compared with rotation $\mathrm{A}$, presumably because their yearly nutrient inputs were somewhat lower. The amount of soil organic carbon $\left(\mathrm{C}_{\mathrm{org}}\right)$, soil water holding capacity, the numbers and biomass of earthworms and the microbial biomass carbon and nitrogen were or tended to be higher in low input/organic than in conventionally managed plots. These effects may be in connection with the slightly increased levels of $\mathrm{C}_{\text {org }}$ in soil of the organic rotations. Activities of twelve enzymes were strongly affected by sampling time (early- versus late-summer), but much less by long-term management. Litter decomposition, numbers of soil nematodes, arbuscular mycorrhizal (AM) fungal diversity, AM spore density and AM functioning were little affected by rotation. However, AM spore density correlated positively with the high amounts of extractable calcium and $P$ which were a result from excessive liming applied to some plots in 1982. The crucial question to be
\end{abstract}




\section{Vestberg, M. et al. Cropping system impact on soil quality determinants}

answered in future is whether plant growth and yield will correlate with the changes in soil properties. This question will be dealt with in a further paper using data from the same experiment.

Key words: liming, soil property, soil quality indicator, soil resilience

\section{Introduction}

Agriculture is today characterized by a high degree of intensity. Heavy machines are repeatedly used during the growing season and crops are often given high amounts of fertilizers and pesticides to maximize yields. To ensure a maximum economic outcome, crops are often also grown as monoculture. Some agricultural soils can stand such cultivation practices, but many gradually show a lower productivity due to an impaired soil quality. In recent years there has been increasing awareness of soil quality to ensure a greater sustainability of agricultural soils. Two main questions are subject to research: (1) Which soil properties most effectively determine the soil quality and can be used as soil quality indicators, and (2) How can soil quality be improved or maintained?

Soil quality has been broadly defined as the capacity of a soil to function within ecosystem boundaries to sustain biological productivity, maintain environmental quality and promote plant and animal health (Doran et al. 1996, Karlen et al. 1997). Until recently, many researchers defined soil quality mainly using chemical and physical terms, but now it is generally accepted that the concept includes physical, chemical and biological properties of the soil (Karlen and Andrews 2000, van Bruggen and Semenov 2000). As soil is characterized by the three above-mentioned properties, indicators related to all of these factors are needed for a complete good description of soil quality (Stenberg 1999). The indicators should respond promptly and accurately to perturbation (Holloway and Stork 1991), but they should not be influenced by natural annual variations such as weather conditions and crop development (Stenberg 1999).
A number of biological soil properties have been reported to respond to changes in agricultural practices, thus having a potential to be used as specific indicators of soil quality. These include general biological properties such as organic matter (Dumontet et al. 2001), soil animals like earthworms (Pfiffner and Mäder 1997) and nematodes (Ferris et al. 2001), and litter decomposition ability (Wardle et al. 1999). Stenberg (1999) listed five different levels at which microorganisms can be studied. There are the (1) individual and (2) population levels (Hill et al. 2000), (3) population on the functional level including autotrophic nitrification (Stenberg et al. 1998), function of arbuscular mycorrhiza (Kahiluoto et al. 2001) and specific soil enzymes and (4) the whole microbial community studied as genetic or physiological diversity, or quantitative methods for the total community including for example microbial biomass (Ananyeva et al. 1999), basal respiration rate (Griffiths et al. 2001), nitrogen mineralization, denitrification (Stenberg et al. 1998) and general soil enzymes (Vepsäläinen et al. 2001). Finally there is the (5) ecosystem level that may be described by data from all the other levels.

It is not possible to use all ecosystem or soil attributes as indictors of soil quality (Karlen and Andrews 2000). Therefore, a minimum data set (MDS) consisting of selected chemical, physical and biological soil properties has been suggested (Doran and Parkin 1996). Descriptive or qualitative indicators have also been suggested. A spade diagnosis method showing basic quality aspects of soils has also been developed especially for use in organic agriculture (Preuschen 1987).

This study was conducted to determine changes in soil chemical and biological properties in a field with 17 years of different crop- 
Vol. 11 (2002): 311-328.

ping histories. The greatest emphasis was put on biological properties as determinants of soil quality. The study site was chosen with a priori assumption that soil quality had developed differently in long-term conventional cereal rotations as compared with long-term low input/organic rotations. One conventional rotation was changed into organic after twelve years, thus enabling us to also track changes due to cropping history.

\section{Material and methods}

\section{Field experiment}

In 1982, a long-term field crop rotation experiment was established on a silt soil at Laukaa Research and Elite Plant Station of MTT Agrifood Research Finland. The soil had a high mean $\mathrm{pH}$ (7.1) but its content of organic carbon $\left(\mathrm{C}_{\text {org }}\right)$ was low, $1.36 \%$. The amounts of acid ammonium acetate extractable phosphorus $(\mathrm{P})$, potassium $(\mathrm{K})$, calcium $(\mathrm{Ca})$ and magnesium $(\mathrm{Mg})$ were $30,84,2156$ and $266 \mathrm{mg} \mathrm{l}^{-1}$ soil, respectively. These values represent, according to the interpretation of soil test results (Viljavuuspalvelu Oy 2000), a good status for $\mathrm{P}, \mathrm{Ca}$ and $\mathrm{Mg}$, but a fair status for K. The experiment consisted of 36 plots arranged in three complete blocks with a plot size of $50 \mathrm{~m}^{2}(5 \mathrm{~m} \times 10 \mathrm{~m}$; width $\times$ length $)$. Each block included four treatments, i.e. rotations $\mathrm{A}-\mathrm{D}$, that were repeated three times (starting points 1-3) by starting a rotation from years 2,4 and 5 . The rotations were 6 years long.

Rotations A and B represented conventional farming and were fertilized using full (A) or half (B) amounts of recommended mineral fertilizers (Table 1). The fertilizers (Kemira, Finland) contained varying amounts of NPK during 19821999 with nutrient applications of $96-102 \mathrm{~kg}$ nitrogen $(\mathrm{N}), 15-42 \mathrm{~kg} \mathrm{P}$ and $45-85 \mathrm{~kg} \mathrm{~K} \mathrm{ha}^{-1}$ for barley (Hordeum vulgare L.) in rotation A. The corresponding amounts for rye (Secale cereale L.) were $40-133 \mathrm{~kg} \mathrm{~N}, 35 \mathrm{~kg} \mathrm{P}$ and $18-$ $85 \mathrm{~kg} \mathrm{~K} \mathrm{ha}^{-1}$. Turnip (Brassica rapa ssp. rapa
L.) was given $85-96 \mathrm{~kg} \mathrm{~N}, 30-42 \mathrm{~kg} \mathrm{P}$ and 60$78 \mathrm{~kg} \mathrm{~K} \mathrm{ha}^{-1}$. Rotations C and D were low-input rotations resembling those used in organic agriculture. In rotation $\mathrm{C}$, crop residues were returned to the plot as such but in rotation $\mathrm{D}$ the crop residues were composted. Rotations $\mathrm{C}$ and $\mathrm{D}$ had a leguminous crop every second year (Table 1). When red clover (Trifolium pratense L.) was cultivated as a preceding crop to rye, it was ploughed down as green manure. To compensate for losses of $\mathrm{P}$ and $\mathrm{K}$ in the yield, rotations $\mathrm{C}$ and $\mathrm{D}$ were also fertilized with Finnish raw phosphate and biotite (Kemira), a K fertilizer; $500 \mathrm{~kg} \mathrm{ha}^{-1}$ and $2000 \mathrm{~kg} \mathrm{ha}^{-1}$, respectively, for the first 6 -year period. For the next 6 -year period the corresponding amounts were $300 \mathrm{~kg} \mathrm{ha}^{-1}$ and $3000 \mathrm{~kg} \mathrm{ha}^{-1}$. Raw phosphate and biotite were added composted to rotation D. At establishment of the experiment, rotations C and D were also given $20 \mathrm{t} \mathrm{ha}^{-1}$ animal manure. The amounts of crop residues returned to the plots in rotations $\mathrm{C}$ and $\mathrm{D}$ varied greatly according to standing crop and year being on average only $553 \mathrm{~kg}$ and $415 \mathrm{~kg}$ dry weight (DW) ha ${ }^{-1}$ on turnip growing plots $C$ and $D$, respectively. Red clover showed the greatest DW accumulation producing on average 7710 and $6997 \mathrm{~kg}$ DW $\mathrm{ha}^{-1}$ in rotations $\mathrm{C}$ and $\mathrm{D}$, respectively. The nutrient composition of returned residues (uncomposted or composted) has not been measured for all crops making a calculation of the returned amounts of nutrients impossible.

In 1994, rotations B, C and D were changed into transitional stage of organic farming, while rotation A continued as a pure cereal rotation by omitting turnip from the rotation. By 1999, all plots of rotations B-D were organic. Rotations $\mathrm{B}$ and $\mathrm{C}$ included three successive years of ley, while rotation D had two successive years of ley at the most (Table 1). Leys and rye were given $15 \mathrm{t} \mathrm{ha}^{-1}$ composted animal manure in the year of establishment before 1997. Thereafter the amount was doubled to $30 \mathrm{t} \mathrm{ha}^{-1}$. During 19941999 the organic rotations B-D received in animal manure lower amounts of extractable $\mathrm{N}$ (84\% lower), P (35\% lower) and K (23\% lower) than rotation A was given in the mineral fertilizer. 
Vestberg, M. et al. Cropping system impact on soil quality determinants

Table 1. Standing crops of rotations A-D of the Laukaa field experiment during 1982-1999.

\begin{tabular}{|c|c|c|c|c|}
\hline \multirow[t]{2}{*}{ Rotation } & \multicolumn{2}{|c|}{ 1982-1993 } & \multicolumn{2}{|c|}{ 1994-1999 } \\
\hline & Description & Crops in rotation & Description & Crops in rotation \\
\hline A & $\begin{array}{l}\text { Conventional, full } \\
\text { mineral fertilization }\end{array}$ & $\begin{array}{l}\text { barley - barley - rye - } \\
\text { oat - turnip - oat }\end{array}$ & Conventional & $\begin{array}{l}\text { barley - barley - rye - } \\
\text { oat - barley - barley }\end{array}$ \\
\hline B & $\begin{array}{l}\text { Conventional, half } \\
\text { mineral fertilization }\end{array}$ & $\begin{array}{l}\text { barley - barley - rye - } \\
\text { oats - turnip - oat }\end{array}$ & Organic rotation 1 & $\begin{array}{l}\text { barley - ley - ley - } \\
\text { ley - rye - pea+oat }\end{array}$ \\
\hline $\mathrm{C}$ & $\begin{array}{l}\text { Low input, plant } \\
\text { residues returned } \\
\text { untreated }\end{array}$ & $\begin{array}{l}\text { barley - red clover - } \\
\text { rye - pea+oat - turnip - } \\
\text { pea+oat }\end{array}$ & Organic rotation 1 & $\begin{array}{l}\text { barley - ley - ley - } \\
\text { ley - rye - pea +oat }\end{array}$ \\
\hline $\mathrm{D}$ & $\begin{array}{l}\text { Low input, plant } \\
\text { residues returned } \\
\text { composted }\end{array}$ & $\begin{array}{l}\text { Barley }- \text { red clover }- \\
\text { rye }- \text { pea+oat }- \text { turnip - } \\
\text { pea }+ \text { oat }\end{array}$ & Organic rotation 2 & $\begin{array}{l}\text { barley - ley - ley - } \\
\text { rye - oat - ley }\end{array}$ \\
\hline
\end{tabular}

Study of the experimental data revealed a hidden error of treatment. Already in 1982 some block 1 plots growing barley in 1999 had received unintentionally a heavy liming treatment. This means that block 1 plots can be regarded as a liming treatment and that the intended treatments were mainly studied on the basis of blocks 2 and 3.

\section{Sampling}

Soil samples were collected in 1983, 1989, 1991 and 1995 for determination of extractable nutrients, $\mathrm{pH}$, electrical conductivity $(\mathrm{EC})$ and $\mathrm{C}_{\mathrm{org}}$. Ten subsamples were collected from the uppermost $20 \mathrm{~cm}$ of each plot and pooled and mixed thoroughly to make the final sample. In 1999, soil samples were collected from plots growing barley at rotation starting point 1 (A1, B1, C1, D1) and from rye plots at rotation starting point 3 (A3, D3). There were two main sampling times; seedling stage (12 June) and harvest (9 August). Earthworms and mycorrhiza were sampled in late September. Table 2 shows soil parameters estimated at different times. In 1999, 20 subsamples were collected from each plot, pooled and mixed to make the final sample (one per plot). The samples were stored at $+6^{\circ} \mathrm{C}$ until the next day. Then they were delivered cooled (soil en- zymes, nematodes), frozen (soil microbial biomass) or air-dried (extractable nutrients, $\mathrm{C}_{\text {org }} \%$ ) to laboratories involved in the study. For studies of mycorrhiza, 10 subsamples per plot were collected from the uppermost $15 \mathrm{~cm}$ of soil. After pooling and mixing one sample per plot was stored at $+6^{\circ} \mathrm{C}$ until use.

\section{Soil analyses}

Extractable nutrients were determined from acid ( $\mathrm{pH} 4.65)$ ammonium acetate $(0.5 \mathrm{M}$ acetic acid, $0.5 \mathrm{M}$ ammonium acetate), (Vuorinen and Mäkitie 1955). Soil $\mathrm{pH}$ was analysed from a soil in water suspension, 1:2.5 (v/v). Water holding capacity (WHC) of sieved soil was measured by soaking the soil samples in water for $30 \mathrm{~min}$ and letting them drain for $0.5-2 \mathrm{~h}$, until equilibrium.

Activities of extracellular soil enzymes were measured using a ZymProfiler ${ }^{\mathrm{TM}}$ as described by Vepsäläinen et al. (2001). Results from blocks 2 and 3 had to be omitted because refrigeration for several days had affected the enzyme activities in a random fashion. The activities of a total of 12 soil enzymes were determined.

The microbial biomass in soil was estimated by a slightly modified fumigation-extraction method of Vance et al. (1987) and Brookes et al. (1985). Briefly, sieved (6 mm) soil samples, 
Vol. 11 (2002): 311-328.

moisture content adjusted to 40-60\% WHC, were fumigated for $24 \mathrm{~h}$ with ethanol-free chloroform (Merck 102444). Immediately after the treatment the fumigated and respective control samples were extracted with $0.5 \mathrm{M} \mathrm{K}_{2} \mathrm{SO}_{4}$. For microbial biomass carbon calculations, total organic carbon was determined from the extracts using a Shimadzu TOC-5050 analyzer. Microbial biomass $\mathrm{N}$ calculations were based on the total $\mathrm{N}$ values analyzed by the Kjeldahl method. K-factors 0.45 and 0.54 for microbial biomass carbon (Wu et al. 1990), and N (Brookes et al. 1985), respectively, were used. The results are expressed on an oven-dry basis $\left(105^{\circ} \mathrm{C}\right.$ over night $)$.

For nematode extraction, soil samples were stored in plastic bags at +3 to $+5^{\circ} \mathrm{C}$. Subsamples of $500 \mathrm{ml}$ of mixed and homogenized samples were taken for analysis. The soil was first mixed carefully in water and then passed through a $0.14-\mathrm{mm}$ sieve, and the remaining soil was disposed of. The rinsed soil was passed through a $0.06-\mathrm{mm}$ sieve and then twice through a 0.042 $\mathrm{mm}$ sieve. After sieving-decanting the rinsed water with soil and nematodes from the last rinsings was poured on the screen of a Baermann funnel coated with a double milk bolting cloth and the funnel was filled with water to reach the lower surface of the sample. A glass tube was attached to the bottom. Escaping nematodes were collected during 3-5 days. The nematodes were counted on a glass grid plate under a stereomicroscope. Samples of the nematodes were prepared for microscopic identification.

Earthworms were sampled from two randomly chosen areas per plot. Both electrical method and hand sorting was used for sampling. For the electrical extraction, an apparatus build according to Thielemann (1987) was used. Eight electrical rods were submerged into the soil $30 \mathrm{~cm}$ deep at regular intervals forming a cylinder with a volume of $0.038 \mathrm{~cm}^{3}$ and a surface area of $0.126 \mathrm{~cm}^{2}$. Electric power of 30 and 60 volts was conducted to the soil for a total of 16 minutes. Earthworms emerging were picked and preserved in $70 \%$ ethanol. Immediately after this the soil cylinder outlined by the rods was removed to a depth of $20 \mathrm{~cm}$. The sample was spread onto a white plastic sheet and earthworms were picked by handsorting and preserved in $70 \%$ ethanol. They were identified and classified into adults, subadults and juveniles. The fresh (preserved) weight was measured with their gut contents.

The effectiveness of indigenous arbuscular mycorrhizal fungal (AMF) populations was estimated in a bioassay using flax (Linum usitatissimum L.) as a test plant (Kahiluoto et al. 2000). In order to create a non-mycorrhizal control, benomyl was mixed with soil at a rate of $20 \mathrm{mg}$ $\mathrm{l}^{-1}$ soil $^{-1}$. The relative mycorrhizal effectiveness (RME), i.e. the mycorrhizal contribution to the growth of the mycorrhizal plant, was defined by the following formula: $R M E(\%)=\left[\left(Y^{m y c+}-\right.\right.$ $\left.\left.Y^{m y c-}\right) /\left(Y^{m y c+}\right)\right] \times 100$ where $Y^{\text {myct }}$ and $Y^{m y c-}$ are the dry weights of the mycorrhizal treatment and control with inhibited AM function, respectively. AM spores were extracted by wet sieving and decanting (Gerdemann and Nicolson 1963) followed by centrifugation in water and in 50\% sucrose solution (Walker et al. 1982). Sieves of $500 \mu \mathrm{m}$ and $50 \mu \mathrm{m}$ were used for wet sieving. After centrifugation the spores were transferred into a dish of water for examination under a dissecting microscope. Thereafter the spores were counted and classified.

Litter decomposition in soil was studied using the mesh bag method (Berg et al. 1987). Airdry clover leaves ( $0.5 \mathrm{~g}$ without petioles) were sealed into polyester bags (mesh size $0.2 \times 0.2$ $\mathrm{mm}$, bag size $5 \times 5 \mathrm{~cm}$ ) that were placed in the soil in upright position, the top $5 \mathrm{~cm}$ below the soil surface and 2-3 cm apart. Two sets of bags with two bags in each set were buried in each experimental plot. One bag in each set was dug up after 30 days and the remaining bags after 60 days. The bags were gently washed and dried at $60^{\circ} \mathrm{C}$ overnight. The dry weight of the remaining clover leaves was measured.

\section{Statistical analyses}

Repeated measurements of response variables (chemical properties and $\mathrm{C}_{\text {org }}$ ) were made from 


\section{Vestberg, M. et al. Cropping system impact on soil quality determinants}

Table 2. Chemical and biological soil properties determined from the experimental area during 1983-1999. Enzyme activities and ATP were calculated per soil loss on ignition (organic matter) and enzyme activities as $\mu$ mol product (MUF $=4$ methylumbelliferone or AMC = 7-amino-4-methylcoumarine) $\mathrm{g}^{-1}$ soil (loi) $3 \mathrm{~h}^{-1}$; xylanase as $\mu \mathrm{mol}$ glucose $\mathrm{g}^{-1}$ soil (loi) $16 \mathrm{~h}^{-1}$.

\begin{tabular}{|c|c|c|c|c|c|c|c|c|}
\hline \multirow[t]{2}{*}{ Property } & \multirow[b]{2}{*}{ Abbreviation } & \multirow[b]{2}{*}{1983} & \multirow[b]{2}{*}{1989} & \multirow[b]{2}{*}{1991} & \multirow[b]{2}{*}{1995} & \multicolumn{3}{|c|}{1999} \\
\hline & & & & & & Jun & Aug & Sep \\
\hline Water holding capacity ( $\mathrm{ml} \mathrm{g}^{-1} \mathrm{dw}$ soil) & WHC & & & & & $\mathrm{x}$ & & \\
\hline $\mathrm{pH}$ & $\mathrm{pH}$ & $\mathrm{x}$ & $\mathrm{x}$ & $\mathrm{x}$ & $\mathrm{x}$ & $\mathrm{x}$ & & \\
\hline Electrical conductivity $\left(10^{-4} \mathrm{~S} \mathrm{~cm}^{-1}\right)$ & $\mathrm{EC}$ & $\mathrm{x}$ & $\mathrm{x}$ & $\mathrm{x}$ & $\mathrm{x}$ & $\mathrm{x}$ & & \\
\hline Extractable phosphorus (mg $\mathrm{l}^{-1}$ dry soil) & $\mathrm{P}$ & $\mathrm{x}$ & $\mathrm{x}$ & $\mathrm{x}$ & $\mathrm{x}$ & $\mathrm{x}$ & & \\
\hline Extractable calcium (mg $\mathrm{l}^{-1}$ dry soil) & $\mathrm{Ca}$ & $\mathrm{x}$ & $\mathrm{x}$ & $\mathrm{x}$ & $\mathrm{x}$ & $\mathrm{x}$ & & \\
\hline Extractable potassium (mg l- dry soil) & $\mathrm{K}$ & $\mathrm{x}$ & $\mathrm{x}$ & $\mathrm{x}$ & $\mathrm{x}$ & $\mathrm{x}$ & & \\
\hline Extractable magnesium (mg $\mathrm{l}^{-1}$ dry soil) & $\mathrm{Mg}$ & $\mathrm{x}$ & $\mathrm{x}$ & $\mathrm{x}$ & $\mathrm{x}$ & $\mathrm{x}$ & & \\
\hline \multicolumn{9}{|l|}{ Enzymes } \\
\hline Acid phosphatase & $\mathrm{PME}_{\mathrm{acid}}$ & & & & & $\mathrm{x}$ & $\mathrm{x}$ & \\
\hline Alkaline phosphatase & $\mathrm{PME}_{\text {alkaline }}$ & & & & & $\mathrm{x}$ & $\mathrm{x}$ & \\
\hline$\alpha$-Glucosidase & $\alpha$-Gluc & & & & & $\mathrm{x}$ & $\mathrm{x}$ & \\
\hline$\beta$-Glucosidase & $\beta$-Gluc & & & & & $\mathrm{x}$ & $\mathrm{x}$ & \\
\hline Arylsulphatase & ArylS & & & & & $\mathrm{x}$ & $\mathrm{x}$ & \\
\hline$\beta$-Xylosidase & $\beta-X y l$ & & & & & $\mathrm{x}$ & $\mathrm{x}$ & \\
\hline Chitinase & Chitin & & & & & $\mathrm{x}$ & $\mathrm{x}$ & \\
\hline Alanine aminopeptidase & Alanine AP & & & & & $\mathrm{x}$ & $\mathrm{x}$ & \\
\hline Leusine aminopeptidase & Leucine AP & & & & & $\mathrm{x}$ & $\mathrm{x}$ & \\
\hline Lysine-alanine AP & Lys Ala AP & & & & & $\mathrm{x}$ & $\mathrm{x}$ & \\
\hline Phosphodiesterase & PDE & & & & & $\mathrm{x}$ & $\mathrm{x}$ & \\
\hline Xylanase & Xyl & & & & & $\mathrm{x}$ & $\mathrm{x}$ & \\
\hline Adenosine triphosphate (nmol g ${ }^{-1}$ (loi) soil) & ATP & & & & & $\mathrm{x}$ & $\mathrm{x}$ & \\
\hline Soil organic carbon $(\%)$ & $\mathrm{C}_{\text {org }}$ & $\mathrm{x}$ & & $\mathrm{x}$ & & $\mathrm{x}$ & & \\
\hline Microbial biomass $\mathrm{N}$ ( $\mu \mathrm{g}$ Nmic $\mathrm{g}^{-1} \mathrm{dw}$ soil) & $\mathrm{N}_{\text {mic }}$ & & & & & $\mathrm{x}$ & $\mathrm{x}$ & \\
\hline Microbial biomass $\mathrm{C}\left(\mu \mathrm{g} \mathrm{Cmic} \mathrm{g}^{-1} \mathrm{dw}\right.$ soil) & $\mathrm{C}_{\text {mic }}$ & & & & & $\mathrm{x}$ & $\mathrm{x}$ & \\
\hline Number of nematodes (no. $500 \mathrm{ml}^{-1}$ soil) & $\mathrm{NEM}_{\text {number }}$ & & & & & & $\mathrm{x}$ & \\
\hline Number of earthworms (no. $\mathrm{m}^{-2}$ soil) & $\mathrm{EW}_{\text {number }}$ & & & & & & & $\mathrm{x}$ \\
\hline Earthworm fresh weight ( $\mathrm{g} \mathrm{m}^{-2}$ soil) & $\mathrm{EW}_{\mathrm{FW}}$ & & & & & & & $\mathrm{x}$ \\
\hline Number of AM spores (no. $100 \mathrm{ml}^{-1}$ soil) & $\mathrm{AM}_{\text {spores }}$ & & & & & & & $\mathrm{x}$ \\
\hline Number of AM species (no.) & $\mathrm{AM}_{\text {species }}$ & & & & & & & $\mathrm{x}$ \\
\hline $\begin{array}{l}\text { Relative mycorrhizal effectivenss, fresh weight } \\
\quad(\text { RME-\%) }\end{array}$ & $\mathrm{RME}_{\mathrm{FW}}$ & & & & & & & $\mathrm{x}$ \\
\hline $\begin{array}{l}\text { Relative mycorrhizal effectivenss, dry weight } \\
\text { (RME-\%) }\end{array}$ & $\mathrm{RME}_{\mathrm{DW}}$ & & & & & & & $\mathrm{X}$ \\
\hline Litter decomposition (\% decomposed) & LD & & & & & $\mathrm{X}$ & & \\
\hline
\end{tabular}

each plot for several years, starting in 1983 and ending in 1999 (Table 2). The repeated measurements from the same plot were correlated and the correlation was taken into account in the statistical models. Proper covariance structure for the repeated measurements was chosen. Unstructured proved useful for $\mathrm{pH}, \mathrm{Mg}, \mathrm{C}_{\text {org }}, \mathrm{P}$ and EC. Compound symmetry proved useful for $\mathrm{Ca}$ and $\mathrm{K}$. The response variables were analysed according to the following mixed model:

$Y_{i j k}=\mu+b_{i}+T_{j}+e_{i j}+P_{k}+f_{i k}+T P_{j k}+g_{i j k}$

where is the overall mean, $b$ is the random block effect, $\mathrm{T}$ and $\mathrm{P}$ are the fixed effect of treatment and year, TP is the two-factor interaction of fixed 
Vol. 11 (2002): 311-328.

Table 3. Amounts of extractable $\mathrm{P}$ and $\mathrm{K}$ in different cropping systems (rotations A-D, see Table 1) in 1983-1999. Analyses were made from starting point 1 of rotations.

\begin{tabular}{|c|c|c|c|c|}
\hline \multirow[t]{2}{*}{ Soil property and year } & \multicolumn{4}{|c|}{ Rotation } \\
\hline & A & $\mathrm{B}$ & $\mathrm{C}$ & $\mathrm{D}$ \\
\hline \multicolumn{5}{|c|}{ Extractable $\mathrm{P}, \mathrm{mg} \mathrm{l}^{-1}$ dry soil } \\
\hline 1983 & 46 & 42 & $31 *$ & 34 \\
\hline 1989 & 33 & 38 & $21 *$ & $23^{*}$ \\
\hline 1991 & 30 & 31 & $19 * *$ & $23 *$ \\
\hline 1995 & 33 & 35 & 18 & 23 \\
\hline 1999 & 31 & 33 & $18 * * *$ & $21 * *$ \\
\hline \multicolumn{5}{|c|}{ Extractable $\mathrm{K}, \mathrm{mg} \mathrm{l}^{-1}$ dry soil } \\
\hline 1983 & 80 & 77 & $72 *$ & 75 \\
\hline 1989 & 97 & 94 & $81 * * *$ & $73 * * *$ \\
\hline 1991 & 92 & 85 & $73 * * *$ & $77 * * *$ \\
\hline 1995 & 86 & 82 & $68 * * *$ & $70 * * *$ \\
\hline 1999 & 108 & 126 & 105 & 102 \\
\hline
\end{tabular}

Means in rows followed by *** or *** differ from the value in rotation A at $P<0.05, P<0.01$ or $P<0.001$ (tested by the ESTIMATE statement of PROC MIXED), respectively.

effects and $\mathrm{e}, \mathrm{f}$ and $\mathrm{g}$ are random error terms. Residual errors $\left(g_{i j k}\right)$ were correlated with the covariance structure defined above. The models were fitted by using the residual maximum likelihood (REML) estimation method. The degrees of freedom were approximated through the method introduced by Kenward and Roger (1997). Accordances of the data with the distributional assumptions of the models were checked by graphic plots. The residuals were checked for normality using box plot (Yandell 1997). In addition, the residuals were plotted against the fitted values. The MIXED of the SAS/STAT software was used in the analyses (Littell et al. 1996).

Soil biological and chemical properties measured from the experiment in 1999 were subjected to cluster analysis that was carried out with ZymProfiler ${ }^{\mathrm{TM}}$ software applying standardization using averages for each variable, squared eucludian distance as dissimilarity measure and UPGMA (group mean) as the clustering method. Results of 1999 were also tested using analysis of variance and Statistix for Windows software (Analytical Software, Thallahassee, USA). Because of the variation between blocks observed in the cluster analysis the impact of blocks was tested in addition to treatment in the two-way analysis of variance. Enzyme activities were measured from both spring and autumn samples of block 1 and were thus analysed using twoway analysis of variance without replication. Only measurement replicates were available and the results must be regarded as tentative. Due to the assumed impact of cultivated plant, rye and barley plots were analysed separately for each soil property.

\section{Results}

\section{Chemical properties 1983-1999}

After one year already, but especially after seven or more years, extractable $\mathrm{P}$ and $\mathrm{K}$ had decreased significantly in rotations $\mathrm{C}$ and D (low input/organic) as compared with the conventional rotation $\mathrm{A}$, but in rotation $\mathrm{B}$ (low mineral fertilization/organic) the contents of these nutrients did not differ from the values measured in A. 
Vestberg, M. et al. Cropping system impact on soil quality determinants

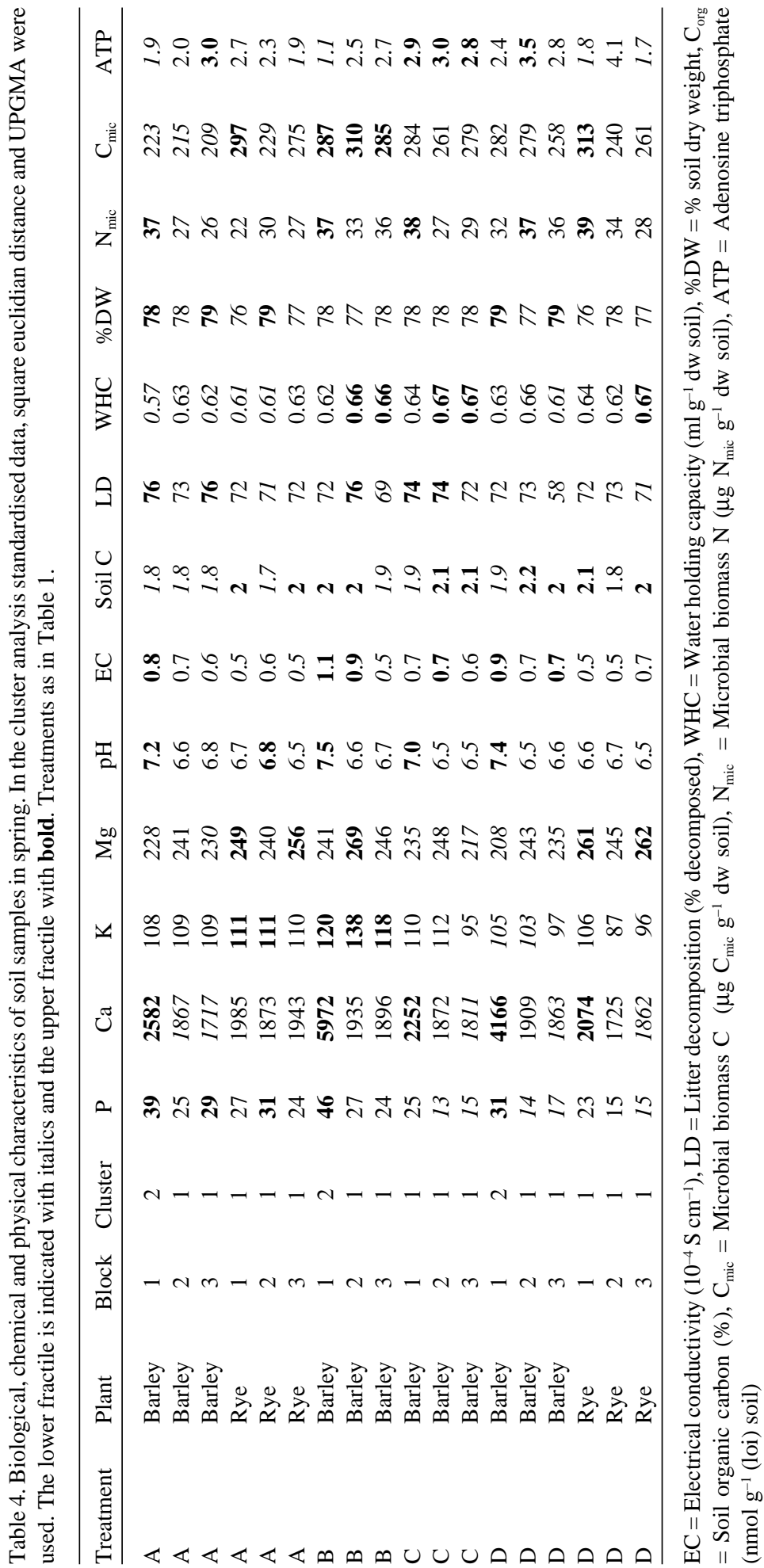


Vol. 11 (2002): 311-328.

Table 5. Statistically significant sources of variation for chemical, physical and biological variables (general analysis of variance).

\begin{tabular}{|c|c|c|c|c|c|}
\hline Variable & Test cover & $\begin{array}{l}\text { Significant source } \\
\text { of variation }\end{array}$ & df & $\mathrm{F}$ & $\mathrm{P}$ \\
\hline \multicolumn{6}{|c|}{ Early summer } \\
\hline \multirow[t]{2}{*}{$\mathrm{P}$} & \multirow[t]{2}{*}{ barley } & treatment & 3,6 & 20.79 & 0.0014 \\
\hline & & block & 2,6 & 37.35 & 0.0004 \\
\hline $\mathrm{Ca}$ & barley & block & 2,6 & 5.17 & 0.0495 \\
\hline $\mathrm{K}$ & barley & treatment & 3,6 & 8.92 & 0.0125 \\
\hline $\mathrm{Mg}$ & barley & block & 2,6 & 5.86 & 0.0388 \\
\hline $\mathrm{Mg}$ & rye & block & 1,2 & 20.67 & 0.0461 \\
\hline $\mathrm{C}_{\text {org }}$ & rye & block & 1,2 & 31.00 & 0.0313 \\
\hline $\mathrm{pH}$ & barley & block & 2,6 & 45.94 & 0.0002 \\
\hline $\mathrm{pH}$ & rye & block & 1,2 & 23.75 & 0.0404 \\
\hline \multicolumn{6}{|c|}{ Early and late summer } \\
\hline $\mathrm{N}_{\text {mic }}$ & barley & treatment & 3,12 & 4.34 & 0.0274 \\
\hline $\mathrm{N}_{\text {mic }}$ & rye & treatment & 1,8 & 8.42 & 0.0198 \\
\hline \multirow[t]{2}{*}{$\mathrm{C}_{\text {mic }}$} & \multirow[t]{2}{*}{ barley } & treatment & 3,12 & 19.01 & $<0.0001$ \\
\hline & & block & 2,12 & 4.04 & 0.0366 \\
\hline $\mathrm{C}_{\text {mic }}$ & rye & block & & 7.34 & 0.0191 \\
\hline \multirow[t]{2}{*}{ ATP } & barley & treatment & 3,12 & 5.22 & 0.0354 \\
\hline & & block & 2,12 & 10.59 & 0.0009 \\
\hline
\end{tabular}

$\mathrm{C}_{\text {org }}=$ Soil organic carbon $(\%), \mathrm{N}_{\text {mic }}=$ Microbial biomass $\mathrm{N}\left(\mu \mathrm{g} \mathrm{N} \mathrm{N}_{\text {mic }} \mathrm{g}^{-1} \mathrm{dw}\right.$ soil $)$,

$\mathrm{C}_{\text {mic }}=$ Microbial biomass C $\left(\mu \mathrm{g} \mathrm{C}_{\text {mic }} \mathrm{g}^{1} \mathrm{dw}\right.$ soil), ATP = Adenosine triphosphate (nmol g ${ }^{-1}$ (loi) soil)

The amount of extractable $\mathrm{P}$ decreased significantly in all rotations (on average $0.6-0.9 \mathrm{mg}$ $1^{-1}$ year $\left.^{-1}\right)$ from 1983 to $1999\left(\mathrm{~F}_{4,32}=9.36, \mathrm{P}<\right.$ 0.01). In spite of the decrease, soil $P$ status was well above a deficiency level in all rotations even at the end of the experimental period, representing a good status in rotations A and B and a satisfactory status in rotations $\mathrm{C}$ and $\mathrm{D}$ (Viljavuuspalvelu Oy 2000). Year affected significantly also the amount of extractable $\mathrm{K}\left(\mathrm{F}_{4,32}=155.69\right.$, $\mathrm{P}<0.001$ ), but in an opposite direction (Table 3 ). Almost all results of $\mathrm{K}$ showed a fair soil $\mathrm{K}$ status throughout the experiment (Viljavuuspalvelu Oy 2000). Thus, the soils were substantially poorer in $\mathrm{K}$ than they were in $\mathrm{P}$. The longterm cropping system had no significant effect on soil pH (mean value 6.8 in 1999), EC (mean value 0.7 in 1999) or amounts of extractable $\mathrm{Ca}$ (mean value $2487 \mathrm{mg} \mathrm{l}^{-1}$ soil in 1999) and $\mathrm{Mg}$ (mean value $237 \mathrm{mg} \mathrm{l}^{-1}$ soil in 1999).

Cluster analysis of the 1999 early summer results revealed that in the barley growing plots of block 1, extractable $\mathrm{P}, \mathrm{Ca}, \mathrm{pH}$ and $\mathrm{EC}$ tended to be higher than elsewhere. In plots of blocks 2 and 3 in rotations $\mathrm{C}$ and $\mathrm{D}, \mathrm{P}, \mathrm{Ca}, \mathrm{K}$ and $\mathrm{pH}$ were lower and WHC was higher (Table 4).

Treatment affected significantly the amounts of extractable $\mathrm{P}$ in the barley plots $(\mathrm{P}=0.0014)$ but not in the rye plots (Table 5). $\mathrm{P}$ concentrations tended to be lower in the organically than in the conventionally cultivated plots but, due to the significant $(\mathrm{P}=0.0004)$ variation between blocks (Table 5), the differences were not consistent. $\mathrm{P}$ concentrations in early summer were at higher level in the barley plots of rotation A but also in block 1 of rotation D. It was highest in rotation B of block 1 (Table 4).

The amount of extractable $\mathrm{Ca}$ was significantly affected by block but not by treatment (Table 5). Ca concentrations were highest in block 1 of the barley growing plots irrespective of treatment (Table 4).

K concentration was significantly affected by treatment in the barley plots in the analysis of 
Vestberg, M. et al. Cropping system impact on soil quality determinants

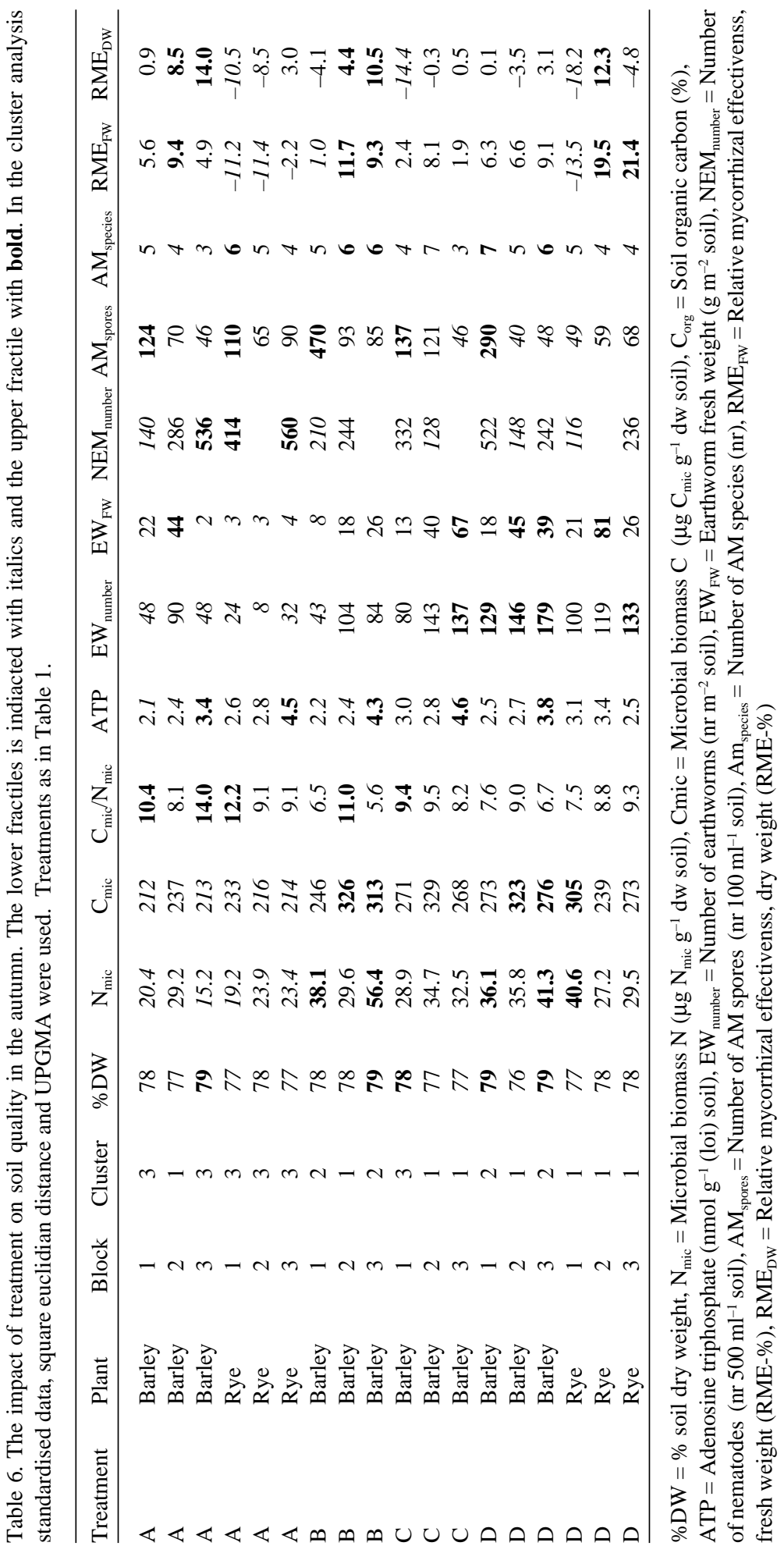


Vol. 11 (2002): 311-328.

variance (Table 5). Organically cultivated plots and blocks 2 and 3 tended to have lower K concentrations than the other plots.

$\mathrm{Mg}$ concentrations were high in the rye plots. Nevertheless, the ranges of $\mathrm{Ca}, \mathrm{K}$ and $\mathrm{Mg}$ concentrations were narrow. Soil $\mathrm{pH}$ tended to be high in block 1 in both the barley and rye plots (Table 4). No significant differences were observed for EC or WHC between plots.

\section{Soil biological quality in spring and autumn 1999}

Cluster analysis performed with the early summer data show high $\mathrm{C}_{\text {org }}$ in blocks 2 and 3 of rotations $\mathrm{C}$ and $\mathrm{D}$. Plots in rotation $\mathrm{A}$ tended to have low microbial biomass $\mathrm{N}$ (Table 4).

The cluster analysis of soil quality variables in autumn (Table 6) reveals a cluster of rye growing plots in rotation A with low quantities of earthworms, high numbers of nematodes and low microbial biomass carbon and N. High quantities of earthworms and low numbers of nematodes tend to be present in organically cultivated rotations $\mathrm{C}$ and $\mathrm{D}$. A positive impact of liming (barley growing block 1) was observed for AM spore numbers.

Enzyme activities were measured only for the liming treatment (block 1). Due to the assumed impact of cultivated plant, rye and barley plots were analysed separately. The impact of season was observed for chitinase, $\beta$-xylosidase and leu- cine aminopeptidase activities, but no significant impact was observed due to treatment. Chitinase and $\beta$-xylosidase activities were high in early summer, but aminopeptidase activies increased towards autumn. (Fig. 1, Table 7). Arylsulphatase activity tended to depend on both the season and treatment. Especially rye growing plots yielded high activities in early summer.

The effects of long-term cropping systems on various biological soil properties other than enzymes are shown in Fig. 2, in Table 5 showing statistically significant differences and in Tables 4 and 6 showing results from all the blocks and indicating clusters. No differences due to treatment were observed for litter decomposition, but $\mathrm{C}_{\text {org }}$ tended to be higher in the organic rotations $\mathrm{B}-\mathrm{D}$ than in the conventional rotation A. Rotation A, especially rye growing plots (A3), yielded lower numbers and biomass of earthworms than the organic rotations $\mathrm{C}$ and $\mathrm{D}$, but the limed plots of block 1 had lower numbers than the other two blocks in rotation C and D. Despite the organic management during 1994-1999, rotation $\mathrm{B}$, especially the limed block 1 , showed also low biomass and numbers of earthworms, thus behaving like the conventional rotation. ATP content was low in block 1 and high in block 3, which hampers comparisons between treatments. High numbers of nematodes were present in all the chemically fertilized rye growing plots but also in the barley growing block 3. Microbial biomass carbon and nitrogen tended to be high in plots of rotation $\mathrm{C}$ and $\mathrm{D}$ but low in the plots

Table 7. Statistically significant sources of variation for adenosine triphosphate and enzyme activitities for barley plots.

\begin{tabular}{lllll}
\hline Variable & $\begin{array}{l}\text { Significant source } \\
\text { of variation }\end{array}$ & df & F & P \\
\hline$\beta$-Xylosidase & season & 1,3 & 24.89 & 0.0155 \\
Chitinase & season & 1,3 & 47.42 & 0.0063 \\
Leucine AP & season & 1,3 & 77.15 & 0.0031 \\
$\beta$-Glucosidase/Biomass N & treatment & 3,3 & 10.19 & 0.0441 \\
$\beta$-Xylosidase/Biomass N & season & 1,3 & 21.72 & 0.0186 \\
Chitinase/Biomass N & season & 1,3 & 21.11 & 0.0194 \\
Leucine AP/Biomass N & season & 1,3 & 14.20 & 0.0327 \\
Lycine-alanine AP/Biomass N & season & 1,3 & 10.33 & 0.0488 \\
\hline
\end{tabular}




\section{AGRICULTURAL AND FOOD SCIENCE IN FINLAND}

Vestberg, M. et al. Cropping system impact on soil quality determinants
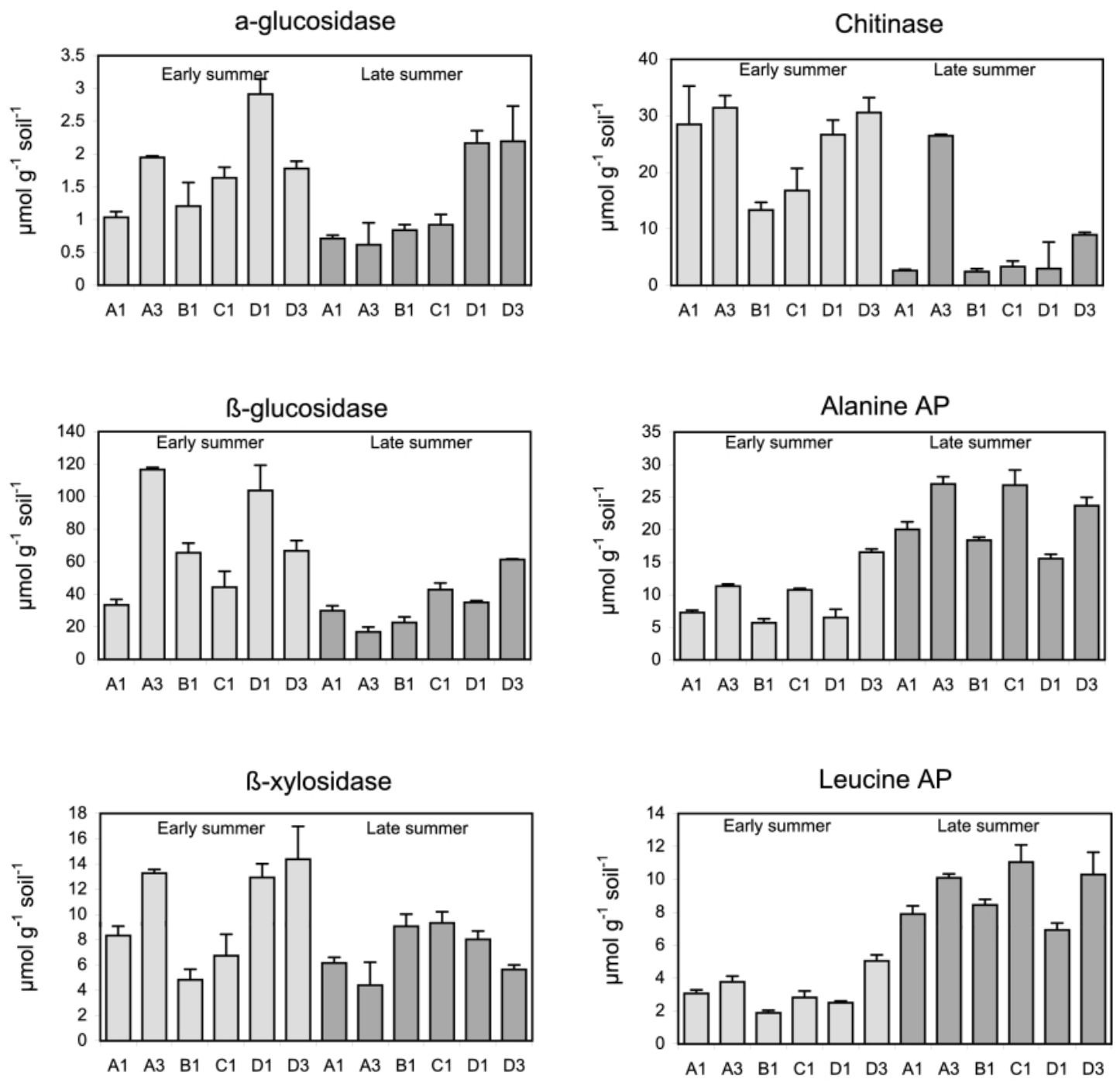

Fig. 1. Soil enzyme activities measured in different cropping systems (see Table 1) in early and late summer of 1999 from block 1. Enzyme activities were calculated per soil loss on ignition (organic matter) as $\mu$ mol product (MUF $=4$-methylumbelliferone or AMC = 7-amino-4-methylcoumarine) $\mathrm{g}^{-1}$ soil (loi) $3 \mathrm{~h}^{-1}$; xylanase as $\mu$ mol glucose $\mathrm{g}^{-1}$ soil (loi) $16 \mathrm{~h}^{-1}$. Vertical lines indicate standard deviation of measurement replicates.

of rotation A in both the barley and rye growing plots.

Diversity of mycorrhiza (number of AM species and spore types identified), ranging from three to seven species per sample, did not correlate with treatment, plant or block. The highest mean species numbers were found in the organ- ic rotations D1 and B1 (6.0 and 5.7 species, respectively), while the lowest numbers were found in rotations A1 and D3 (4.0 and 4.3 species, respectively). Spores belonging to the genus Glomus, especially G. mosseae and G. geosporum, were dominating. Sporadically, also spores of the genera Acaulospora and Scutel- 


\section{AGRICULTURAL AND FOOD SCIENCE IN FINLAND}

Vol. 11 (2002): 311-328.
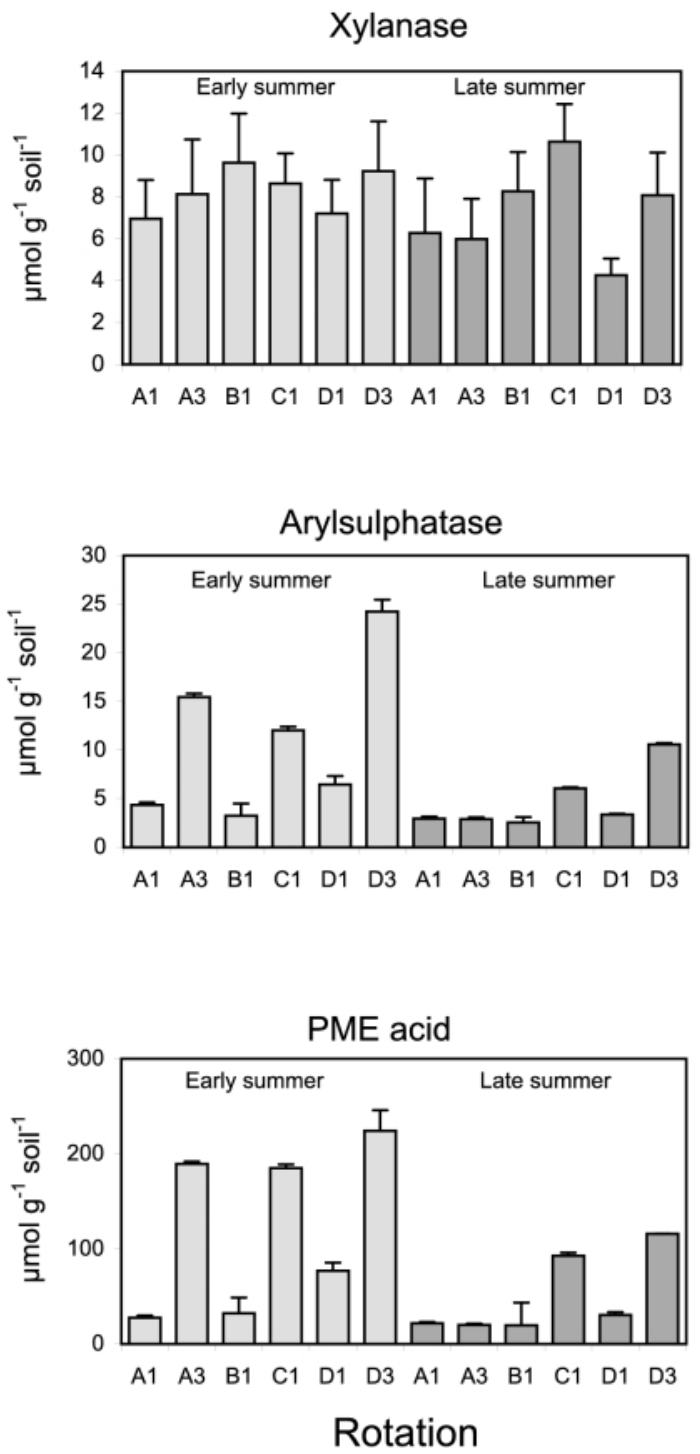

Fig. 1. continues.

lospora were detected. The unintended liming treatment of some plots of block 1 had caused a strong increase of spores belonging to the genus Glomus. The AMF spore numbers correlated positively with the amounts of soil $\mathrm{Ca}(\mathrm{r}=0.98)$, soil $\mathrm{P}(\mathrm{r}=0.69), \mathrm{pH}(\mathrm{r}=0.83)$ and $\mathrm{EC}(\mathrm{r}=0.76)$. In the RME test the overall impact of the indig-
Lysine-alanine AP
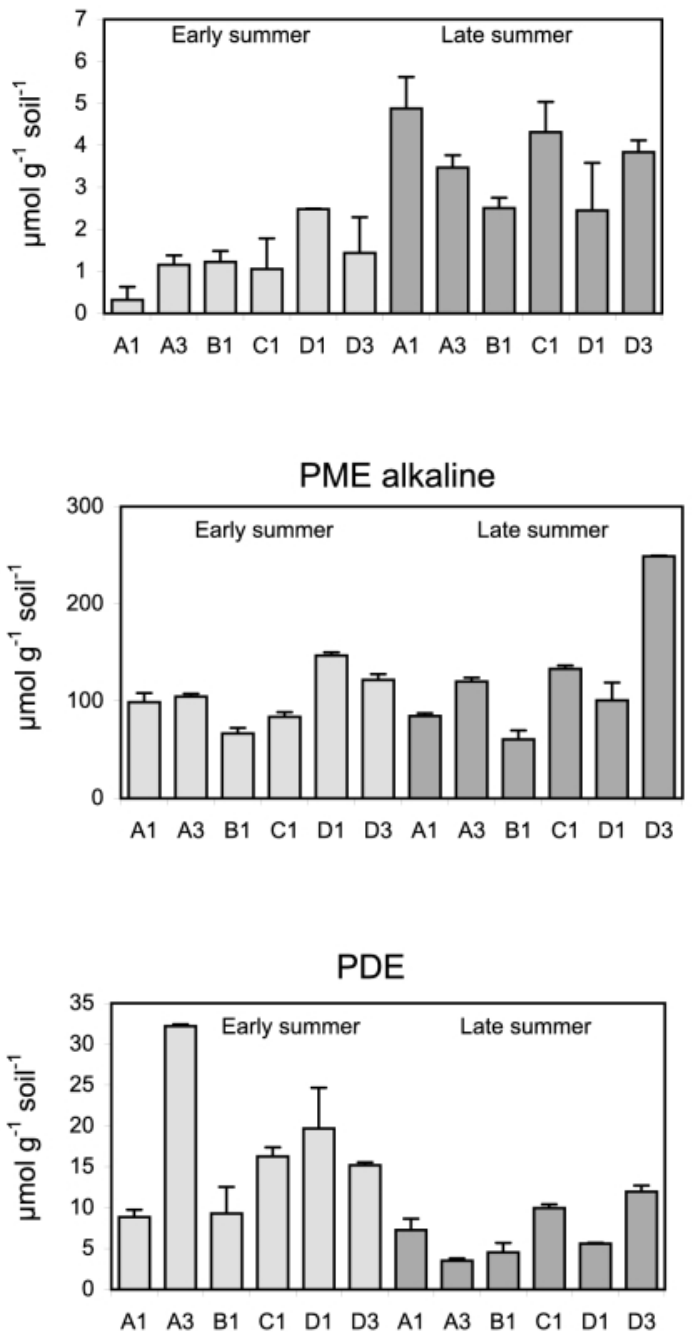

Rotation enous AM fungal populations on flax growth was small, although a slight positive effect of AMF was observed in barley plots of rotation A. There were, however, great variation in RME values between blocks with block 1 (both barley and rye plots) yielding lower values than the other blocks (Fig. 2, Table 6). 


\section{AGRICULTURAL AND FOOD SCIENCE IN FINLAND}

Vestberg, M. et al. Cropping system impact on soil quality determinants
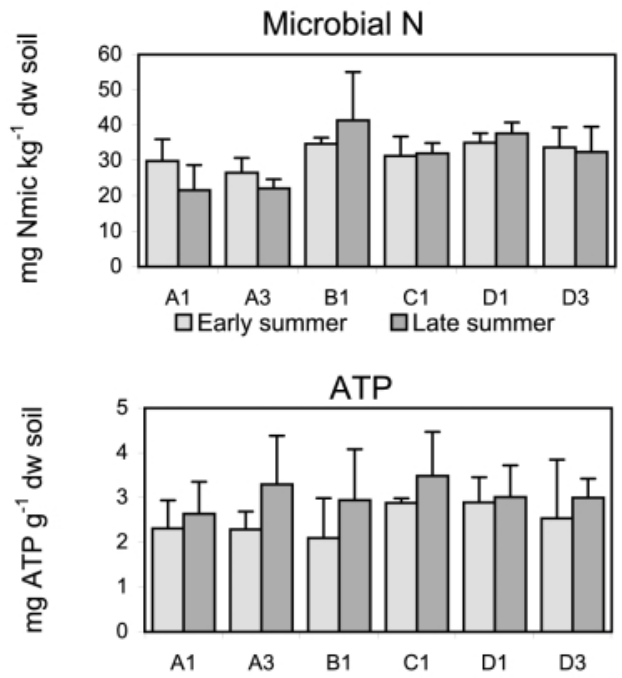

口Early summer aLate summer

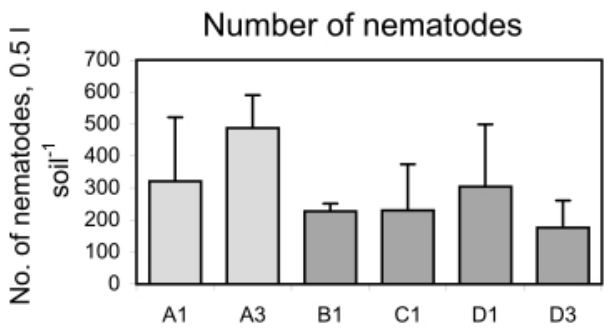

Earthworm weight
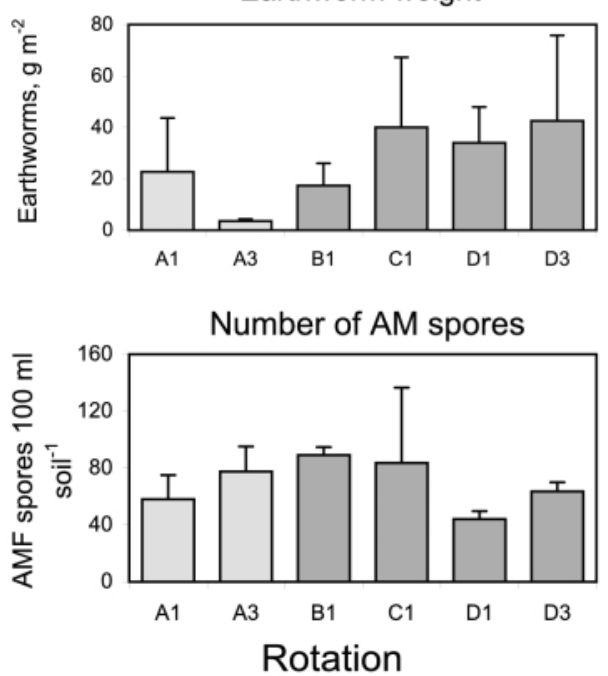
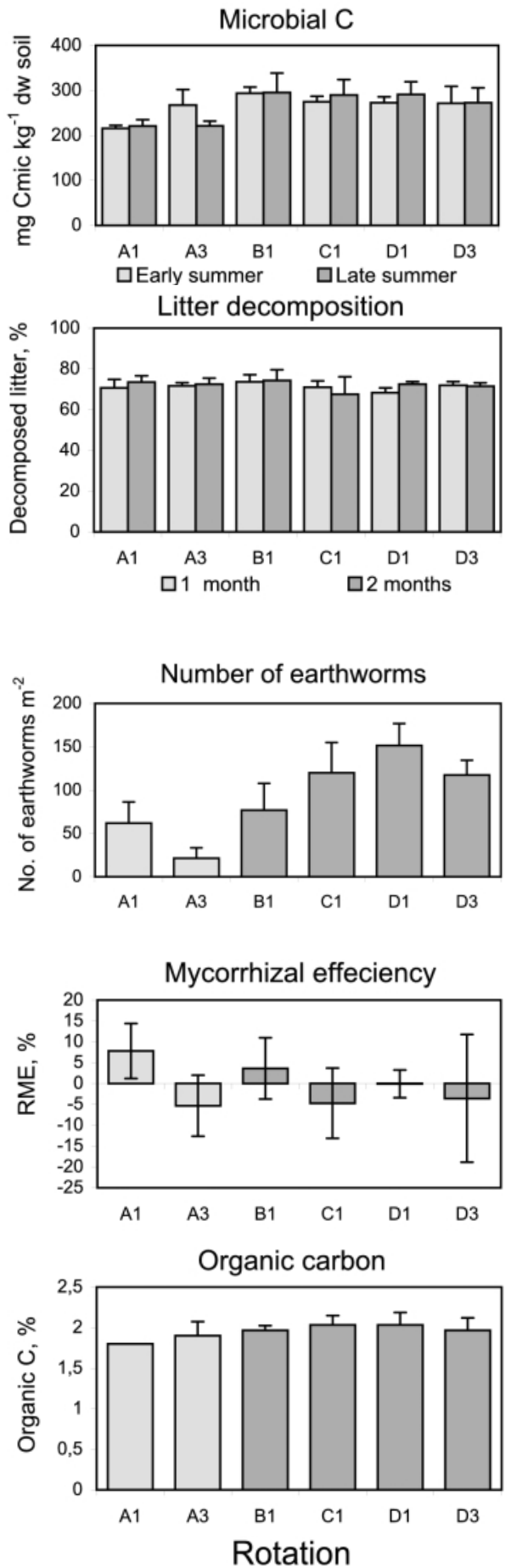

Fig. 2. Soil biological properties measured in different cropping systems (see Table 1) in early and late summer of 1999. Means of three blocks except for numbers of AM spores which are means of block 2 and 3. Vertical lines indicate standard deviation of means. 
Vol. 11 (2002): 311-328.

\section{Discussion}

Soil biological and chemical properties were studied in a field experiment during and after 17 years of different cropping systems. Although the impact of cropping system on soil properties was seldom statistically significant, several soil properties had changed or showed an indication of change in response to a long-term cropping history. These were extractable $\mathrm{P}$ and $\mathrm{K}, \mathrm{WHC}, \mathrm{C}_{\text {org }}$, soil microbial biomass carbon and $\mathrm{N}$ and number of earthworms. These results are only partly in agreement with an earlier Finnish study where long-term organic farming was shown to decrease soil extractable $\mathrm{P}$ levels and to increase microbial biomass N (Palojärvi et al. 2000). The reason for the differences between these two studies may be found in the $\mathrm{C}_{\text {org }}$ levels. The soil in the Laukaa experiment had a very low initial $\mathrm{C}_{\text {org }}$ content which was increased in the low input/organic rotations. Although this increase of $\mathrm{C}_{\text {org }}$ was very small it may have influenced the soil properties listed above. The big differences in the number of earthworms cannot be explained by the small increase in $\mathrm{C}_{\mathrm{org}}$. The organically managed plots may have provided occasionally more and better food for the earthworms than the conventionally managed plots. This organic material was however easily decomposed and did not cause big increase in $\mathrm{C}_{\text {org }}$. The lower levels of $\mathrm{P}$ and $\mathrm{K}$ in organically managed plots as compared with conventionally managed plots was probably due to a lower $\mathrm{P}$ and $\mathrm{K}$ fertilization during the last five years in those plots. Soil enzyme activities were mainly affected by sampling time, and the impact of treatment on enzyme activities must be evaluated, paying simultaneously attention to crop, plant and season. A long-term effect of liming was also detected as increased concentrations of $\mathrm{Ca}$ and $\mathrm{P}$, higher $\mathrm{pH}$ and $\mathrm{EC}$, and increases in $\mathrm{AM}$ spore numbers.

The results were characterized by a high degree of variation which influenced the results of statistical tests. The soils of different plots were subject to a long-term influence of crop rotation and fertilizer management, crop rotation effect.
The influence of cropping system on soil properties was the main objective of this study. However, soil properties were also subject to the effect of the standing crop (barley or rye in this case) or of the preceding crop the year before. There were also very great variation between blocks for some characteristics. Furthermore, season (time of sampling) had a distinct effect, especially on soil enzyme activities.

Replicate enzyme activity measurements yielded sufficiently small variation. Enzyme activities differed distinctly in the barley and rye growing plots but management practice did not clearly affect enzyme activities in the analysis of variance where season was a more important factor. This lack of impact may be due to the insensitive statistical analysis without replicates. On the other hand, the impact of liming possibly masked the impact of rotation. Only the block 1 plots which had received unintentionally lime in 1982 were analysed for enzyme activities. In the cluster analysis the slight differences are summed up if they occurred simultaneously. This sensitivity of cluster analysis is evident with the present set of data because of the rare significant impact of treatment in the analysis of variance, whereas cluster analysis showed differences related to treatment (Vepsäläinen et al. 2001). Vepsäläinen et al. (2001) made a tentative observation with this set of data that the plots that had earlier received composted plant material and the plots receiving mineral fertilisers belonged to separate clusters. However, it is an interesting finding that may be confirmed with the new data that will be available from this experiment later on.

Despite five years of organic management during 1994-1999 in rotation B, soil P and K and the amounts and biomass of earthworms were still closer to the levels prevailing in the conventional rotation A than in the organic rotations that had run over a longer period. This is an example of slow soil resilience after a big change of management. The above-mentioned variation between blocks of the experimental area was at least partly due to an unintentionally given high amount of lime in certain plots of 


\section{Vestberg, M. et al. Cropping system impact on soil quality determinants}

block 1 in 1982. This liming treatment was still detected after 17 years as increased levels of $\mathrm{Ca}$ and $\mathrm{P}$, higher $\mathrm{pH}$ and $\mathrm{EC}$ and higher numbers of spores of AM fungi. The liming treatment can therefore be regarded as another example of slow soil resilience.

This study can be seen as one of the first attempts to find properties of importance for determination of soil quality in Finnish agriculture. However, reliable indicators of soil quality can be chosen only after certain criteria have been met. Several authors (Brookes 1993, Doran and Parkin 1996) list such criteria and they are summarized by Stenberg (1999) into five essential points: (1) indicators should integrate physical, chemical and biological properties and processes and represent soil properties or functions that are more difficult to measure directly, (2) the ecological relevance and natural variation of indicators should be well understood, (3) indicators should be sensitive to long-term variation in management and climate, but resistant to short-term fluctuations due to weather change or crop development, (4) it should be possible to measure indicators accurately and precisely across a wide range of soil types and soil conditions and (5) indicators should be simple to assess and cost efficient to allow for a large number of analyses to be made.

It can be concluded that long-term field experiments as the one used by us or others (e.g. Svensson 2002) are valuable tools for studying changes in soil quality. In our study, the cropping system affected several soil properties including both chemical and biological ones. These soil characteristics have a potential to be chosen as soil quality indicators. However, biological properties often also showed great variation in response to standing crop and season. In further studies, the reasons for this variation need to be studied. Search for indicators less sensitive to prevailing environmental conditions should also be emphasized. The crucial question to be answered in future is whether plant growth and yield will correlate with the changes in soil properties. This question will be dealt with in a further paper using data from the same experiment.

Acknowledgements. This study was financed by the Ministry of Agriculture and Forestry, by a special grant from MTT Agrifood Research Finland and the National Technology Agency of Finland as a project of the Biodiversity Research Programme of the Academy of Finland. The field experiment was carried out at the Laukaa Research and Elite Plant Station of MTT Agrifood Research Finland where some laboratory analyses were also carried out. Other analyses were carried out in the laboratories of MTT in Jokionen (Plant Protection and Soils and Environment) and the Finnish Environment Institute in Helsinki. We wish to thank the staff of all the laboratories for doing these analyses. We are particularly grateful to Mauri Räkköläinen at Laukaa for sorting out research results during the long period from 1982 to 1999 and to Christian Eriksson at MTT in Jokioinen for help with the statistical analyses. We also wish to thank Sevastiana Ruusamo, M.A., for valuable revision of the English manuscript.

\section{References}

Ananyeva, N.D., Demkina, T.S., Jones, W.J., Cabrera, M.L. \& Steen, W.C. 1999. Microbial biomass in soils of Russia under long-term management practices. Biology and Fertility of Soils 29: 291-299.

Berg, B., Müller, M.M. \& Wessen, B. 1987. Decomposition of red clover (Trifolium pratense) roots. Soil Biology and Biochemistry 19: 589-593.

Brookes, P.C. 1993. The potential of microbiological properties as indicators in soil pollution monitoring. In: Schulin, R. et al. (eds.). Soil monitoring: Early detection and surveying of soil contamination and degradation. Birkhäuser, Basel. p. 229-254.
Brookes, P.C., Landman, A., Pruden, G. \& Jenkinson, D. S. 1985. Chloroform fumigation and the release of soil nitrogen: A rapid direct extraction method to measure microbial biomass nitrogen in soil. Soil Biology \& Biochemistry 17: 837-842.

Doran, J.W. \& Parkin, T.B. 1996. Quantitative indicators of soil quality: a minimum data set. In: Doran, J.W. \& Jones, A.J. (eds.). Methods for Assessing Soil Quality. SSSA Special Publication no 49. Madison, WI. p. 25-37.

Doran, J.W., Sarrantonio, M. \& Liebig, M.A. 1996. Soil health and sustainability. Advances in Agronomy. 56: 
Vol. 11 (2002): 311-328.

$2-54$.

Dumontet, S., Mazzatura, A., Casucci, C. \& Perucci, P. 2001. Effectiveness of microbial indexes in discriminating interactive effects of tillage and crop rotations in a Vertic Ustorthens. Biology and Fertility of Soils 34: 411-416.

Ferris, H., Bongers, T. \& de Goede, R.G.M. 2001. A framework for soil food web diagnostics: extension of the nematode faunal analysis concept. Applied Soil Ecology 18: 13-29.

Gerdemann, J.W. \& Nicolson, T.H. 1963. Spores of mycorrhizal Endogone species extracted from soil by wet sieving and decanting. Transactions of the British Mycological Society 46: 235-244.

Griffiths, B.S., Bonkowski, M., Roy, J. \& Ritz, K. 2001. Functional stability, substrate utilisation and biological indicators of soils following environmental impacts. Applied Soil Ecology 16: 49-61.

Hill, G.T., Mitkowski, N.A., Aldrich-Wolfe, L., Emele, L.R., Jurkonie, D.D., Ficke, S., Maldonado-Ramirez, S., Lynch, S.T. \& Nelson, E.B. 2000. Methods for assessing the composition and diversity of soil microbial communities. Applied Soil Biology 15: 25-36.

Holloway, J.D. \& Stork, N.E. 1991. The dimensions of biodiversity: the use of invertebrates as indicators of human impact. In: Hawksworth, D.L. (ed.). The Biodiversity of Microorganisms and Invertebrates: Its role in Sustainable Agriculture. WEFSA 1. Vol. 4. CAB International. London. p. 37-62.

Kahiluoto, H., Ketoja, E. \& Vestberg, M. 2000. Creation of a non-mycorrhizal control for a bioassay of AM effectiveness. 1. Comparison of methods. Mycorrhiza 9: 241-258.

Kahiluoto, H., Ketoja, E., Vestberg, M. \& Saarela, I. 2001. Promotion of AM utilization through reduced $P$ fertilization. 2. Field studies. Plant and Soil 231: 65-79.

Karlen, D.L. \& Andrews, S.S. 2000. The soil quality concept: A tool for evaluating sustainability. In: Elmholt, S. et al. (eds.). Soil stresses, quality and care. Proceedings from the NJF seminar 310, Ås, Norway, 1012 April 2000. DIAS Report No. 38. Plant Production. p. 15-26.

Karlen, D.L., Mausbach, M.J., Doran, J.W., Cline, R.G., Harris, R.F. \& Schuman, G.E. 1997. Soil quality: a concept, definition, and framework for evaluation (a guest editorial). Journal of the American Society of Soil Science 61: 4-10.

Kenward, M.G. \& Roger, J.H. 1997. Small sample inference for fixed effects from restricted maximum likelihood. Biometrics 53: 983-997.

Littell, R.C., Milliken, G.A., Stroup, W.W. \& Wolfinger, R.D. 1996. SAS system for mixed models. SAS Institute Inc, Cary, NC, USA. 633 p.

Palojärvi, A., Alakukku, L., Martikainen, E., Niemi, M., Vanhala, P., Jörgensen, K. \& Esala, M. 2000. Soil biological, chemical and physical properties in fields under different management practices. In: Elmholt, S. et al. (eds.). Soil stresses, quality and care. Proceedings from the NJF seminar 310 , Ås, Norway, 1012 April 2000. DIAS Report No. 38. Plant Production. p. 109-113.

Pfiffner, L. \& Mäder, P. 1997. Effects of biodynamic, organic and conventional production systems on earthworm populations. Entomological research in organic agriculture. Biological Agriculture and Horticulture 15: 3-10.

Preuschen, G. 1987. Die Kontrolle der Bodenfruchtbarkeit. Eine Anleitung zur Spatendiagnose. IFOAM-Sonderausgabe Nr. 2. SÖL. Kaiserslautern. $36 \mathrm{p}$.

Stenberg, B. 1999. Monitoring soil quality of arable land: Micorbiological indicators. Review article. Acta Agriculturæ Scandinavica. Section B, Soil and Plant Science 49: 1-24.

Stenberg, B., Pell, M. \& Torstensson, L. 1998. Integrated evaluation of variation in biological, chemical and physical soil properties. Ambio 27: 9-15.

Svensson, K. 2002. Microbial indicators of fertility in arable land. Acta Universitatis Agriculturae Sueciae. Agraria 330. Swedish University of Agricultural Sciences, Department of Microbiology, Uppsala. 53 p. + 4 app.

Thielemann, U. 1986. Elektrischer regenwurmfang mit der oktett-methode. Pedobiologia 29: 296-302.

van Bruggen, A.H.C. \& Semenov, A.M. 2000. In search of biological indicators for soil health and disease suppression. Applied Soil Ecology 15: 13-24.

Vance, E.D., Brookes, P.C. \& Jenkinson, D.S. 1987. An extraction method for measuring soil microbial biomass C. Soil Biology \& Biochemistry 19: 703-707.

Vepsäläinen, M., Kukkonen, S., Vestberg, M., Sirviö, H. \& Niemi, R.M. 2001. Application of soil enzyme activity test kit in a field experiment. Soil Biology and Biochemistry 33: 1665-1672.

Viljavuuspalvelu Oy 2000. Viljavuustutkimuksen tulkinta peltoviljelyssä. Viljavuuspalvelu Oy. $31 \mathrm{p}$.

Vuorinen, J. \& Mäkitie, O. 1955. The method of soil testing in Finland. Agrogeological Publication 63: 1-44.

Walker, C., Mize, C.W. \& McNabb, H.S. 1982. Populations of endogonaceous fungi at two locations in lowa. Canadian Journal of Botany 60: 2518-2529.

Wardle, D.A., Yeates, G.W., Nicholson, K.S., Bonner, K.I. \& Watson, R.N. 1999. Response of soil microbial biomass dynamics, activity and plant litter decomposition to agricultural intensification over a seven-year period. Soil Biology and Biochemistry 31: 1707-1720.

Wu, J., Joergensen, R.G., Pommerening, B. \& Chaussod, R. 1990. Measurement of soil microbial biomass C by fumigation-extraction - an automated procedure. Soil Biology \& Biochemistry 22: 1167-1169.

Yandell, B.S. 1997. Practical data analysis for designed experiments. Chapman \& Hall. 437 p. 


\title{
AGRICULTURAL AND FOOD SCIENCE IN FINLAND
}

Vestberg, M. et al. Cropping system impact on soil quality determinants

\section{SELOSTUS}

\section{Viljelyjärjestelmän vaikutus maan kasvukuntoa määrääviin tekijöihin}

\author{
Mauritz Vestberg, Sanna Kukkonen, Kaisa Saari, Marjatta Uosukainen, Ansa Palojärvi, \\ Tuomo Tuovinen, Milja Vepsäläinen ja Maarit Niemi \\ MTT (Maa- ja elintarviketalouden tutkimuskeskus) ja Suomen ympäristökeskus
}

\begin{abstract}
Viljelyjärjestelmän vaikutusta maan kasvukunnon biologisiin ja kemiallisiin tekijöihin tutkittiin MTT:n Laukaan tutkimus- ja valiotaimiaseman pitkäaikaisessa kenttäkokeessa. Tutkimuksessa verrattiin neljän viljelykierron vaikutuksia maaperäominaisuuksiin. Tavanomaisessa viljelykierrossa (A) viljeltiin lähinnä viljakasveja (ohra-ohra-ruis-kaura-nauris-kaura vuoteen 1993, jonka jälkeen ohra-ohra-ruis-kauraohra-ohra), jotka lannoitettiin suositusten mukaisesti. Kierto A jatkui tavanomaisena viljanviljelynä perustamisvuodesta 1982 vuoteen 1999 asti. Kierto B oli vuoteen 1993 asti muuten A:n kaltainen, mutta sitä lannoitettiin $50 \%$ vähemmän. Kierrot $\mathrm{C}$ ja $\mathrm{D}$ olivat vuoteen 1993 asti omavaraisia kiertoja, joten niiden typpilannoitus oli peräisin kiertoihin sisältyvistä palkokasveista (ohra-puna-apila-ruis-hernekaura-naurishernekaura). Lisäksi näille kierroille annettiin karjanlantaa (vain kokeen alussa), biotiittia ja raakafosfaattia korvaamaan sadon mukana poistunutta kaliumia ja fosforia. Kierrosta C kaikki palautukset kynnettiin käsittelemättöminä maahan, kun taas D-kierrosta palautukset kompostoitiin. Vuonna 1994 kierrot B ja C muutettiin luonnonmukaisen viljelyn siirtymävaihekierroksi 1 (ohra-nurmi-nurmi-nurmi-ruis-hernekaura) ja kierto D luonnonmukaisen viljelyn siirtymävaihekierroksi 2 (ohra-nurmi-nurmi-ruis-kaura-nurmi). Koealueelle tehtiin viljavuusanalyysit vuosina 1983 , 1989, 1991, 1995 ja 1999. Lisäksi vuonna 1999 määritettiin erilaisia biologisia ominaisuuksia koealueen viljaa kasvavista ruuduista.
\end{abstract}

Kiertojen C ja D maaperässä oli vähemmän liukoista fosforia ja kaliumia kuin A-kierron maaperässä. Viljelyjärjestelmä ei sen sijaan vaikuttanut maan pH- tai johtolukuun eikä maan kalsiumin ja magnesiumin määriin. Jotkut biologiset ominaisuudet olivat reagoineet viljelyjärjestelmään ja toiset eivät. Maan mikrobien typen ja hiilen määrä sekä lierojen lukumäärä ja biomassa olivat luomukierroissa suurempia kuin tavanomaisessa kierrossa. Myös maan orgaanisen hiilen määrä ja vedenpidätyskapasiteetti olivat yleensä suurempia luomu- kuin tavanomaiskierroissa. Sen sijaan vuodenaika vaikutti enemmän kahdentoista maaperäentsyymin aktiivisuuksiin. Ankeroisten määrä, orgaanisen aineksen hajoamisnopeus, mykorritsan määrä ja toiminta eivät juuri muuttuneet viljelyjärjestelmän muuttuessa.

Kenttäkokeen perustamisvaiheessa vuonna 1982 oli pienelle alueelle tapahtunut kalkitusvirhe, joka vielä 17 vuotta myöhemmin näkyi kohonneina kalsium-, fosfori-, pH- ja johtolukuina alueella. Maa "muistaa" äärikäsittelynsä pitkään. Ylimääräinen kalkitus ei kuitenkaan heijastunut maaperän biologisiin ominaisuuksiin paitsi mykorritsaitiöiden määrään, joka kasvoi yllä mainittujen kemiallisten ominaisuuksien kohotessa. Toinen esimerkki maan muistista on B-kierto, jonka fosforin ja kaliumin sekä lierojen määrät vuonna 1999 olivat lähempänä A-kierron lukuja kuin C- ja D-kierron lukuja. Tässä tutkimuksessa yritettiin määrittää keskeisiä biologisia maaperäominaisuuksia, joita voitaisiin tulevaisuudessa ottaa käyttöön pelto- ja puutarhamaan kasvukunnon mittareina. 